\title{
Perancangan dan Pengujian Lensa Fresnel pada Kolektor Surya Plat Datar
}

\author{
Ekadewi A. Handoyo ${ }^{1 *}$, Indriati Njoto Bisono², Peter Jonathan ${ }^{3}$ \\ 1,Program Studi Teknik Mesin Fakultas Teknologi Industri Universitas Kristen Petra \\ 2,Program Studi Teknik Industri Fakultas Teknologi Industri Universitas Kristen Petra \\ Jl. Siwalankerto 121-131 Surabaya 60236 Indonesia \\ 3,PT. Anugerah Cipta Ekamulia Surabaya Indonesia \\ * Penulis korespondensi; E-mail: ekadewi@petra.ac.id
}

\begin{abstract}
ABSTRAK
Energi matahari dapat dikonversikan menjadi energi termal dengan menggunakan kolektor surya maupun menjadi energi listrik dengan menggunakan sel surya/photovoltaic. Radiasi matahari bersifat menyebar, sehingga memerlukan pengumpul atau pengarah agar lebih fokus. Ada banyak penelitian yang menggunakan lensa Fresnel untuk mengumpulkan radiasi matahari pada sel surya. Sedang penelitian lensa Fresnel pada kolektor surya masih terbatas sebagai concentrator. Makalah ini_membahas perancangan dan pemakaian lensa Fresnel sebagai penutup pada suatu kolektor surya plat datar. Lensa Fresnel komersial hanya memiliki 1 titik fokus, maka langkah pertama penelitian adalah merancang lensa Fresnel dengan enam titik fokus. Jarak focus dirancang agar radiasi matahari jatuh ke plat penyerap pada jarak $90 \mathrm{~mm}$ dari lensa Fresnel. Bahan yang digunakan adalah PMMA Polymethyl methacrylate (acrylic) dan pembuatan profil lensa menggunakan proses tekan. Lensa Fresnel yang dihasilkan berhasil memiliki titik fokus $90 \mathrm{~mm}$. Lensa Fresnel yang dihasilkan dipasang sebagai penutup pada kolektor surya plat datar. Hasil yang didapat adalah temperatur plat penyerap dengan lensa Fresnel lebih tinggi daripada dengan acrylic polos yang sebenarnya lebih bening. Temperatur maksimum di kiri atas plat penyerap dengan lensa Fresnel dapat mencapai 1.42 kali lebih tinggi daripada temperatur yang dihasilkan oleh acrylic polos. Temperatur cairan di inlet dan dalam tangki pada kolektor surya yang menggunakan lensa Fresnel lebih tinggi daripada temperatur cairan di kedua lokasi yang sama yang menggunakan acrylic polos.
\end{abstract}

Kata kunci: Lensa fresnel; lensa non imaging; kolektor surya plat datar.

\begin{abstract}
A solar cell is used to generate electrical energy from solar radiation and a solar collector is used to heat air or water. Since solar radiation is scattered, then it needs concentrator to focus on certain area. There are many researches on Fresnel lens used in solar cell, but not so many in solar collector. In solar thermal area, more research is conducted on concentrator instead of on collector. This paper will discuss about designing and using Fresnel as cover on flat-plate solar collector. Since the commercial Fresnel lens has only one focus, the first step is to design a Fresnel lens with six 90-mm focus. The gap between Fresnel-lens cover and absorber plate is the focus, i.e. $90 \mathrm{~mm}$. The Fresnel lens is made of PMMA Polymethyl methacrylate (acrylic) and manufactured with pressing process. The Fresnel lens is successfully designed and have the expected focus, i.e. 90 mm.Fresn el lens used as cover on flat-plat solar collector. The results are the plat temperature with Fresnel is higher than with acrylic. The maximum temperature on top-left of plate with Fresnel lens is 1.42 higher than with acrylic which is much clearer. The coolant temperature at inlet and inside the tank using Fresnel lens are also higher than using acrylic.
\end{abstract}

Keywords: Fresnel lens; non-imaging lens; flat plat solar collector.

\section{PENDAHULUAN}

Radiasi matahari merupakan sumber energi terbarukan yang berlimpah di Indonesia. Lama matahari bersinar setiap hari hampir sama sepanjang tahun, karena letak Indonesia di khatulistiwa.
Energi matahari dapat dikonversikan menjadi energi termal dengan kolektor surya maupun menjadi energi listrik dengan sel surya/photovoltaic. Energi listrik tentu sangat diperlukan terutama di daerah yang sulit dijangkau PLN. Namun, kolektor surya merupakan peralatan yang sangat sederhana 
dibandingkan sel surya, baik dari pembuatan maupun perawatan. Panas yang diserap dalam suatu kolektor surya dapat digunakan untuk memanaskan air atau udara.

Sebagai negara agraris yang terletak di daerah tropis, diperlukan pemanas udara untuk berbagai paska panen dari produk pertanian. Udara panas yang dihasilkan dapat digunakan untuk proses pengeringan produk pertanian agar produk pertanian tersebut dapat disimpan lebih lama. Udara panas juga diperlukan untuk proses pengeringan dari berbagai produk olahan hasil pertanian, misalnya pengeringan krupuk atau kripik dari berbagai produk olahan hasil pertanian tersebut. Pada umumnya, pengeringan dilakukan dengan penjemuran di bawah matahari secara langsung. Hal ini mempunyai kelemahan: produk olahan pertanian menjadi kurang higienis dan hanya dapat dilakukan pada siang hari. Sedang kolektor surya dapat menghasilkan air panas yang dapat disimpan untuk meneruskan proses pengeringan pada malam hari ketika tidak ada matahari. Bahkan, air panas ini juga dapat digunakan di rumah kaca untuk memelihara tanaman yang memerlukan penanganan khusus.

Proses konversi energi radiasi dari matahari yang baik dapat meningkatkan output yang berguna bagi kehidupan manusia. Matahari merupakan sumber energi terbarukan yang bersih, sehingga tidak menimbulkan polusi dan aman bagi lingkungan hidup. Berbagai upaya untuk meningkatkan kinerja kolektor surya adalah membuat aliran fluida menjadi lebih turbulen dengan menambahkan obstacle pada permukaan plat penyerap (Handoyo, et al., 2016), (Esen, 2008) fin atau baffle (Romdhane, 2007), memberi kekasaran pada permukaan plat penyerap (Bhushan \& Singh, 2010), membuat aliran dua laluan (Esen, 2008), membuat aliran recycle (Yeh \& Ho, 2009), membuat bentuk plat penyerap berbeda (Gao, et al., 2007), (Handoyo, et al., 2014), mengurangi kerugian panas dengan pipa vakum untuk memanaskan air dalam kolektor surya (Külcü, 2017). Sedang upaya yang dapat diterapkan pada kolektor surya dan sel surya/photovoltaic adalah dengan menambahkan sistem pelacak matahari (Deb \& Roy , 2012), dan concentrator untuk mengarahkan sinar matahari (Zhang, et al., 2013).

Lensa Fresnel dapat diaplikasikan pada kolektor surya untuk meningkatkan temperatur fluida yang dipanaskan. Sebagai contoh, di Romania Luminosu, et al. mengaplikasikan lensa Fresnel untuk memfokuskan radiasi matahari ke suatu titik atau garis (Luminosu, De Sabata, \& Jurca, 2017). Contoh lain adalah Soriga dan Neaga menggunakan lensa Fresnel untuk mengarahkan radiasi matahari ke penerima cahaya yang terbuat dari dua pipa kaca yang se-sumbu (disebut cylindrical cavity receiver). Permukaan sebelah dalam dari pipa kaca diberi lapisan yang memantulkan cahaya. Radiasi matahari terperangkap di ruang antara pipa kaca sebelah dalam dengan sebelah luar. (Soriga \& Neaga, 2012), (Xie, et al., 2011). Lensa Fresnel non-imaging dapat mengarahkan sinar matahari dan ketika digunakan bersamaan dengan alat palacak matahari, lensa Fresnel tersebut dapat mengurangi kerugian karena alat pelacak tidak mengarah kepada matahari (Kumar, et al., 2015). Jika radiasi matahari diterima oleh lensa Fresnel, maka radiasi langsung dan radiasi diffuse dapat dipisahkan oleh lensa Fresnel. Radiasi langsung tidak disukai tanaman tertentu yang pertumbuhannya dilakukan di dalam suatu rumah kaca dan hal ini mengurangi kebutuhan pendinginan ketika kondisi panas (Sonneveld, et al., t.thn.). Lensa Fresnel juga dapat digunakan sebagai CSP (Concentrator Solar Power). Sinar matahari difokuskan ke pipa dengan lensa Fresnel linier yang berfungsi seperti cermin. Fresnel SuperNova yang dibuat oleh Novatec Solar dapat menghasilkan uap hingga $480^{\circ} \mathrm{C}$. Uap ini digunakan untuk memanaskan fluida lain untuk menggerakkan siklus tenaga Rankine (Zhu, et al., 2014). Ketika Lensa Fresnel digunakan untuk memfokuskan radiasi matahari pada suatu PV (photovoltaic), efek tidak langsung adalah temperatur PV meningkat dan hal ini menurunkan kinerja PV. Itu sebabnya dibuat sistem hybrid PVT photovoltaic thermal (Kasaeian, et al., 2018).

Lensa Fresnel dapat digunakan untuk tiga aplikasi, yaitu sebagai collimator, collector, dan condensor atau diverger. Collimator membuat cahaya keluar secara paralel dari lensa. Collector berfungsi untuk memfokuskan collimated beam pada suatu titik focal atau poin. Condensor atau diverger membuat collimated beam berpendar kearah bidang yang lebih luas (Leutz \& Suzuki, 2001). Secara garis besar, lensa Fresnel terbagi dua kelompok, yaitu: imaging dan non-imaging sistem (Leutz \& Suzuki, 2001). Bayangan dari sumber yang dibentuk oleh Lensa Fresnel kelompok imaging jatuh di titik fokus, sedang bayangan dari sumber yang dibentuk oleh lensa Fresnel non imaging tidak jatuh di titik fokus. Lensa imaging akan menghasilkan bayangan benda, sedangkan lensa non-imaging tidak dapat menghasilkan bayangan benda. Lensa Fresnel ini dibuat dikarenakan lebih ringan dan lebih mudah untuk dimanufaktur dari lensa plano-convex (Leutz \& Suzuki, 2001). Lensa Fresnel non-imaging dapat mentransfer sinar cahaya dari sumber ke titik target dengan lebih baik. Selain itu, lensa non-imaging juga mempunyai beberapa keuntungan, seperti dapat menerima cahaya dengan sudut datang lebih lebar, lebih toleran terhadap ketidaktepatan dalam proses pembuatan dan penggunaan, tetap dapat bekerja dengan baik meskipun peralatan pelacak sinar matahari kurang akurat. Hal-hal ini membuat lensa Fresnel non-imaging sering digunakan sebagai solar concentrator (Kumar, et al., 2015). Lensa Fresnel non- 
imaging terbuat dari banyak segmen dengan penampang datar, sedang lensa imaging menggunakan segmen dengan penampang bentuk lengkung. Saat ini, plastik dapat digunakan untuk bahan lensa Fresnel untuk mengkonsentrasikan energi matahari. Plastik tersebut adalah acryl, rigid vinyl dan polycarbonate (PMMA) (Xie, et al., 2011).

Lensa Fresnel dapat digunakan untuk meningkatkan konversi energi surya menjadi energi termal maupun energi listrik dengan menjadi solar concentrator. Lensa Fresnel sangat ringan dan lebih tipis dibandingkan lensa konvensional. Lensa Fresnel non imaging dapat digunakan untuk mengarahkan cahaya agar terpusat di suatu titik (spot) atau di suatu garis/pipa (linear). Suatu kolektor surya memerlukan kaca penutup untuk mengurangi panas yang hilang dari plat penyerap. Kaca penutup terbuat dari bahan yang bening yang dapat mentransmisi sinar matahari sebanyak-banyaknya ke plat penyerap. Panas yang diserap plat penyerap diteruskan ke fluida kerja, misalnya udara atau air. Lensa Fresnel komersial yang ada di pasaran biasanya digunakan sebagai pembesar bayangan, seperti pada OHP overhead projector atau pemancar cahaya seperti pada berbagai lampu sorot atau lampu mercu suar. Lensa Fresnel ini hanya memiliki satu titik focus. Hal ini kurang tepat untuk pemakaian di kolektor surya. Lensa Fresnel belum banyak digunakan sebagai kaca penutup kolektor surya. Oleh karenanya, dirancang suatu lensa Fresnel yang dapat digunakan dalam banyak peralatan yang memanfaatkan radiasi matahari, seperti kolektor surya pemanas udara atau air. Rancangan lensa Fresnel dibuat dan diuji pada suatu kolektor surya plat datar pemanas air.

\section{METODE}

Merancang lensa Fresnel non-imaging dilakukan sesuai kaedah dan ketentuan yang ada di literatur (Leutz \& Suzuki, 2001). Karena digunakan pada kolektor surya plat datar, maka titik fokus lensa Fresnel dirancang sama dengan jarak antara lapisan penutup dengan plat penyerap. Jarak titik fokus dalam penelitian ini ditentukan sebesar $90 \mathrm{~mm}$, sesuai hasil dari penelitian sebelumnya (Handoyo, et al., 2020). Lensa Fresnel dirancang agar cahaya matahari dapat difokuskan ke satu titik pada plat penyerap, agar konversi energi radiasi menjadi energi termal lebih baik. Profil bentuk lensa Fresnel yang dirancang diilustrasikan dalam Gambar 1 .

Perancangan lensa Fresnel menggunakan prinsip Hukum Snellius. Cahaya matahari yang datang dengan sudut $\theta_{i}$ dari garis normal bidang lensa mengalami pembiasan sesuai persamaan (1):

$$
n_{i} \sin \theta_{i}=n_{i+1} \sin \theta_{i+1}
$$

Menerapkan Hukum Snellius dalam merancang lensa Fresnel terlihat dalam Gambar 2. Sinar matahari datang dengan sudut $\theta_{1}$ dari udara dengan indeks bias $n_{1}$ dan mengalami pembiasan dalam lensa Fresnel yang terbuat dari PMMA (acrylic) dengan indeks bias $n_{2}$ sehingga sinar membentuk sudut $\theta_{2}$. Sudut diukur dari garis normal bidang lensa. Ketika sinar matahari akan ke luar dari lensa, sudut yang dibentuk adalah $\theta_{3}$ dan sinar matahari mengalami pembiasan dengan sudut $\theta_{4}$ ketika sinar matahari meninggalkan lensa di bagian bawah. Sinar yang meninggalkan lensa dari semua sisi diharapkan jatuh di titik fokus yang terletak pada plat penyerap. Sudut yang dirancang adalah sudut $\theta_{1}$ yang membuat sinar matahari yang datang di gigi mana pun akan jatuh di titik fokus.

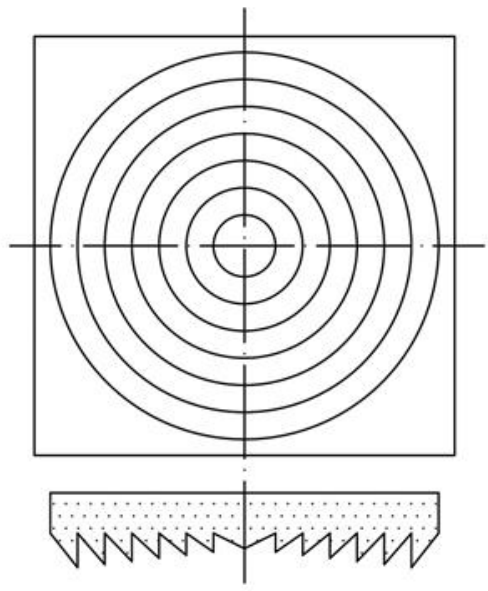

Gambar 1. Profil dari lensa Fresnel yang dirancang

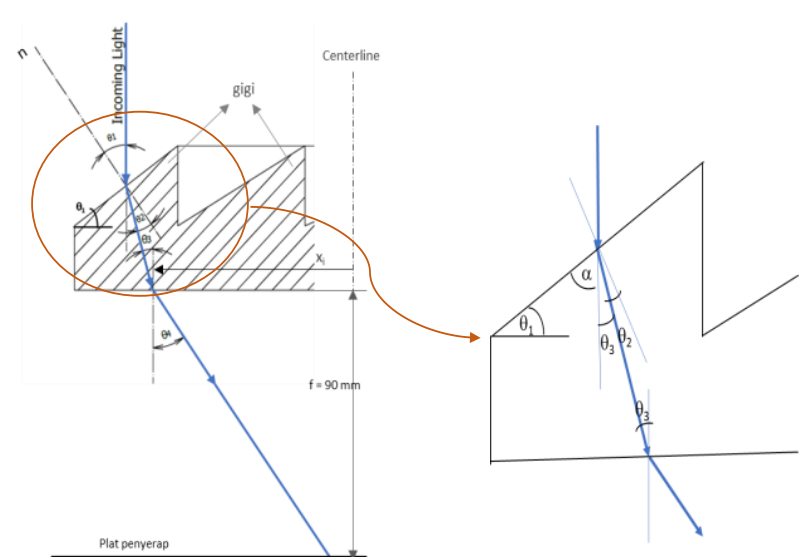

Gambar 2. Cahaya matahari yang datang mengalami pembiasan dalam lensa Fresnel

Dengan titik focus sebesar $90 \mathrm{~mm}$, kemudian ditentukan $x$ dan $y$ dari sinar yang datang. Nilai $y$ sama dengan jarak fokus yaitu $90 \mathrm{~mm}$ dan nilai $x$ sama dengan jarak gigi ke- $i$ dari lensa Fresnel yang diukur dari titik tengah lensa atau centerline.

Dari Gambar 2 terlihat bahwa sudut $\theta_{4}$ dapat dihitung dengan persamaan (2):

$$
\theta_{4}=\tan ^{-1} x_{i} / y_{i}
$$


Sudut $\theta_{3}$ didapat dengan menggunakan Hukum Snellius seperti ditunjukan pada persamaan (3):

$$
n_{3} \sin \theta_{3}=n_{4} \sin \theta_{4}
$$

Dengan mengikuti aturan segitiga seperti pada Gambar 2 sebelah kanan, maka berlaku $\theta_{1}=\theta_{2}+\theta_{3}$ Sudut $\theta_{1}$ dan $\theta_{2}$ dapat dihitung dengan Hukum Snellius: $n_{1} \sin \theta_{1}=n_{2} \sin \theta_{2}$ kan;

Dengan substitusi $\theta_{2}=\theta_{1}-\theta_{3}$, maka didapat-

$$
\begin{gathered}
n_{1} \sin \theta_{1}=n_{2} \sin \left(\theta_{1}-\theta_{3}\right) \\
\frac{\sin \theta_{1}}{\sin \left(\theta_{1}-\theta_{3}\right)}=\frac{n_{2}}{n_{1}} \\
\frac{\sin \theta_{1}}{\sin \theta_{1} \cos \theta_{3}-\cos \theta_{1} \sin \theta_{3}}=\frac{n_{2}}{n_{1}} \\
\sin \theta_{1}=\frac{n_{2} \sin \theta_{1} n_{2} \cos \theta_{3}-n_{2} \cos \theta_{1} n_{2} \sin \theta_{3}}{n_{1}}
\end{gathered}
$$

Untuk mempermudah penghitungan, diasumsikan variable a dan b sebagai berikut:

Maka:

$$
\begin{gathered}
a=\frac{n_{2}{ }^{2} \sin \theta_{3}}{n_{1}}, \quad b=\frac{n_{2}{ }^{2} \sin \theta_{3}}{n_{1}} \\
\sin \theta_{1}=a \sin \theta_{1}-b \cos \theta_{1}
\end{gathered}
$$

$$
\begin{gathered}
(1-a) \sin \theta_{1}=-\mathrm{b} \cos \theta_{1} \\
\tan \theta_{1}=\frac{-b}{1-a}
\end{gathered}
$$

Dengan demikian $\theta_{1}$ dapat dihitung dan $\theta_{1}$ adalah sudut dari gigi lensa Fresnel ke- $i$. Untuk gigi yang lain ditentukan dengan cara serupa, hanya nilai $\mathrm{x}_{\mathrm{i}}$ yang berbeda.

Setelah perancangan selesai, langkah berikutnya membuat prototipe lensa Fresnel. Pembuatan lensa dari bahan PMMA (acrylic) dengan proses pressing memerlukan mould/cetakan. Lensa yang dihasilkan diuji berapa jarak focus-nya dan digunakan sebagai lapisan penutup kolektor surya plat datar pemanas air.

Kolektor surya yang digunakan dalam pengujian ini seperti tampak pada Gambar 3. Kolektor yang dibuat memiliki dimensi $210 \mathrm{~mm}$ x $300 \mathrm{~mm}$, mengikuti lensa Fresnel yang dapat dibuat oleh bengkel rekanan. Karena perpipaan dan tangki yang digunakan terbuat dari besi, maka fluida kerja yang digunakan selama pengujian bukanlah air, melainkan coolant untuk menghindari korosi. Kolektor diberi kemiringan $37^{\circ}$ dari bidang horizontal agar fluida coolant dalam pipa menerima radiasi matahari dengan optimal (Handoyo, et al., 2013).

Coolant akan mengalir secara gravitasi dari tangki menuju pipa-pipa yang diletakkan di atas plat penyerap yang dicat warna hitam. Coolant akan mengalami pemanasan dan naik kembali ke dalam tangki karena efek thermosiphon. Fluida yang lebih panas akan memiliki kerapatan lebih rendah, sehingga lebih ringan dan cenderung naik ke atas.
Pengujian lensa Fresnel pada kolektor surya plat datar pemanas air dilakukan di ruang terbuka di area kampus Universitas Kristen Petra pada bulan November 2019. Besaran yang diukur meliputi intensitas radiasi matahari, temperatur plat di beberapa titik, temperatur udara sekitar, temperatur coolant pada masukan (inlet) dan temperatur coolant dalam tangki. Intensitas radiasi matahari diukur dengan menggunakan pyranometer Kipp \& Zonen, tipe SP Lite2 yang diletakkan pada permukaan datar terdekat dengan kolektor surya tempat lensa Fresnel diuji. Temperatur udara sekitar dan temperatur coolant diukur dengan Thermocouple tipe $\mathrm{K}$ yang dipasang pada logger agar dapat mencatat temperatur dari waktu ke waktu.

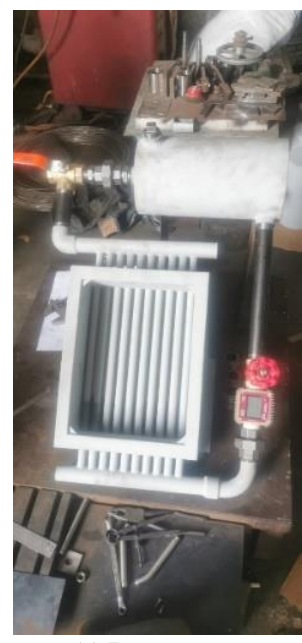

(a) Perpipaan

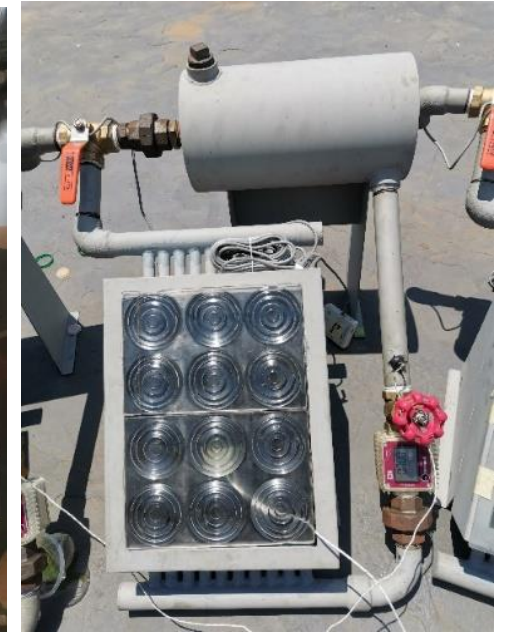

(b) lensa Fresnel hasil rancangan

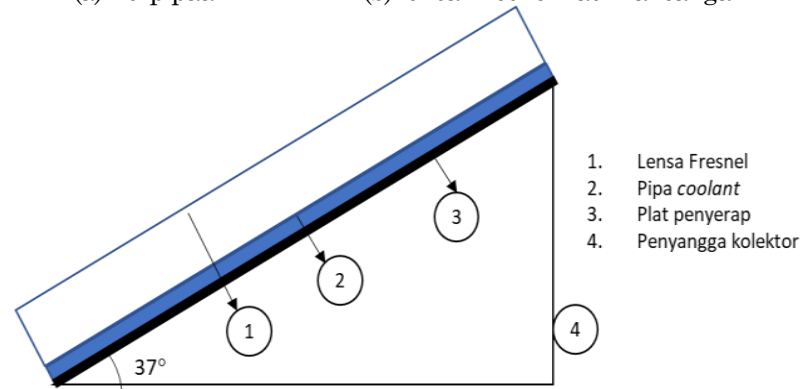

(c) susunan pipa di atas plat penyerap

Gambar 3. Kolektor surya plat datar yang digunakan dalam pengujian lensa Fresnel

\section{HASIL DAN PEMBAHASAN}

Lensa Fresnel dirancang dengan beberapa titik fokus, agar sinar matahari lebih banyak yang difokuskan pada plat penyerap. Dari hasil perhitungan, rancangan lensa Fresnel memiliki bentuk dan profil seperti pada Gambar 4. Karena keterbatasan mesin tekan yang dimiliki rekanan, maka lensa Fresnel dibuat dengan dimensi $150 \mathrm{~mm}$ x $210 \mathrm{~mm}$ dari bahan PMMA setebal 6,71 mm. Namun, profil lensa Fresnel tetap dibuat seperti hasil desain perhitungan di atas dan memiliki bentuk profil seperti pada Gambar 4. 
Cetakan atau mould dibuat menggunakan material baja seperti pada Gambar 5 (a). Cetakan dibuat dengan mesin cnc, sehingga memiliki ketelitian yang baik. Hal ini juga didukung dengan bukti bahwa lensa Fresnel yang dihasilkan memiliki jarak fokus seperti hitungan yaitu $90 \mathrm{~mm}$ atau $9 \mathrm{~cm}$. Sedang lensa Fresnel yang berhasil dibuat dapat dilihat pada Gambar 5 (b).
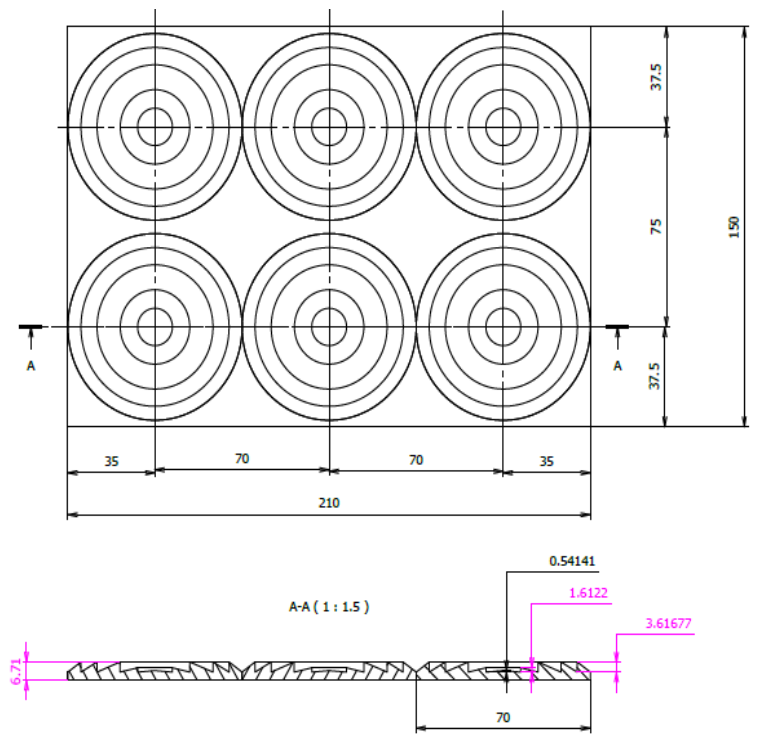

Gambar 4. Hasil perhitungan untuk profil lensa Fresnel

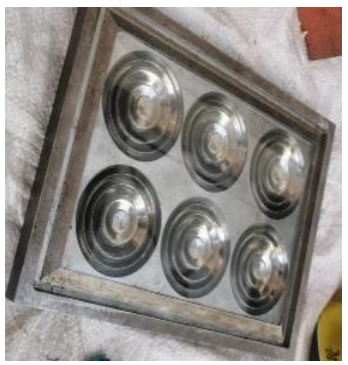

(a) mould/cetakan

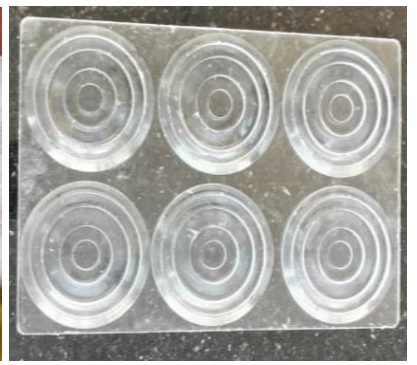

(b) lensa Fresnel rancangan sendiri

Gambar 5. Matras dan lensa Fresnel hasil rancangan sendiri

Titik fokus Lensa Fresnel hasil rancangan sendiri diuji dan benar memiliki titik fokus $90 \mathrm{~mm}$ seperti tampak pada Gambar 6. Hal ini menunjukkan perhitungan dan pembuatan lensa Fresnel memberikan hasil yang benar. Terdapat enam titik fokus pada lensa Fresnel karena ketersediaan tempat yang terkait dengan mesin press yang digunakan untuk mencetak lensa Fresnel.

Pengujian lensa Fresnel pada kolektor surya dilakukan pada dua kolektor dengan penutup berbeda, yaitu Lensa Fresnel hasil rancangan sendiri (sebelah kiri) dan acrylic polos (sebelah kanan) seperti pada Gambar 7. Thermocouple dipasang di plat penyerap kedua kolektor dengan posisi sama seperti yang tampak pada kolektor kanan yang jauh lebih transparan dibandingkan yang sebelah kiri.

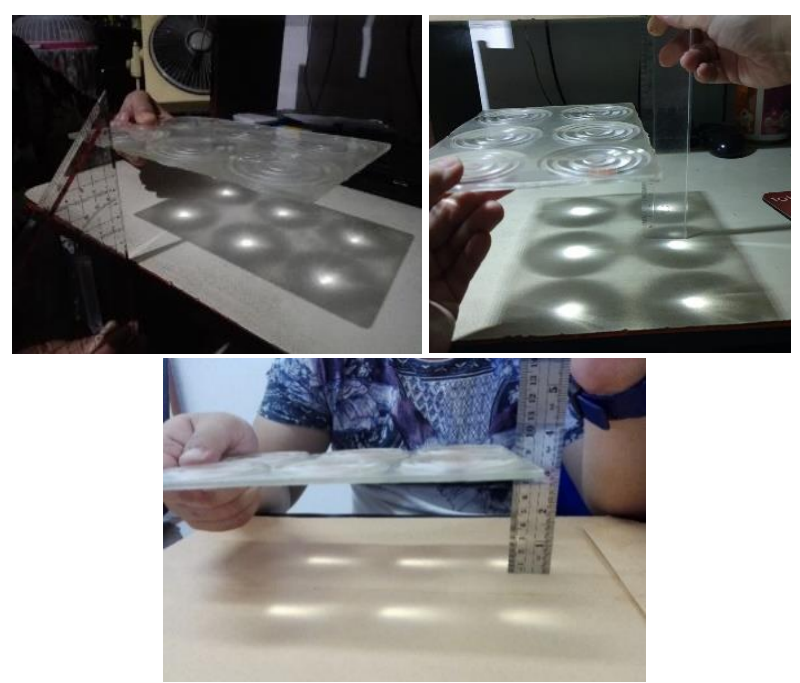

Gambar 6. Lensa Fresnel buatan sendiri dengan titik focus $90 \mathrm{~mm}$

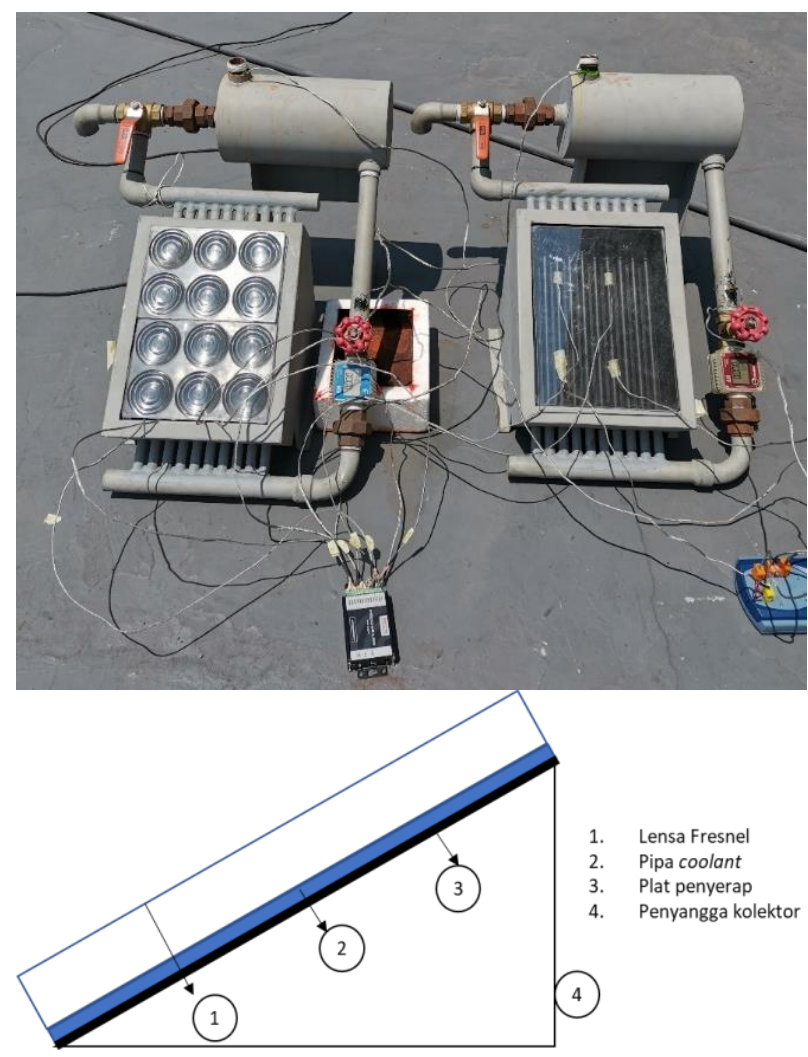

Gambar 7. Lensa Fresnel diuji bersama acrylic polos pada kolektor surya pemanas air

Hasil pengujian lensa Fresnel pada kolektor surya dapat dilihat pada Gambar 8 sampai Gambar 10. Gambar 8 menunjukkan temperatur plat penyerap yang terletak di bawah lensa Fresnel. Temperatur plat sebelah atas baik kiri maupun kanan lebih tinggi daripada temperature plat sebelah bawah, terutama ketika pukul 14.00 - 14.25 WIB. Kolektor diarahkan ke Barat selama pengujian setelah pukul 13.00 WIB. Matahari langsung menembus lensa Fresnel maupun acrylic di rentang 
pukul 14.00 - 14.25 WIB. Setelah itu, sudut matahari mulai landai menuju terbenam. Karena pengujian dilakukan di Surabaya yang terletak sedikit pada belahan Bumi Selatan, maka pada bulan November matahari cenderung lebih ke Selatan. Hal ini menyebabkan temperatur plat sebelah kanan bawah paling tinggi ketika semakin sore seperti pada Gambar 8.

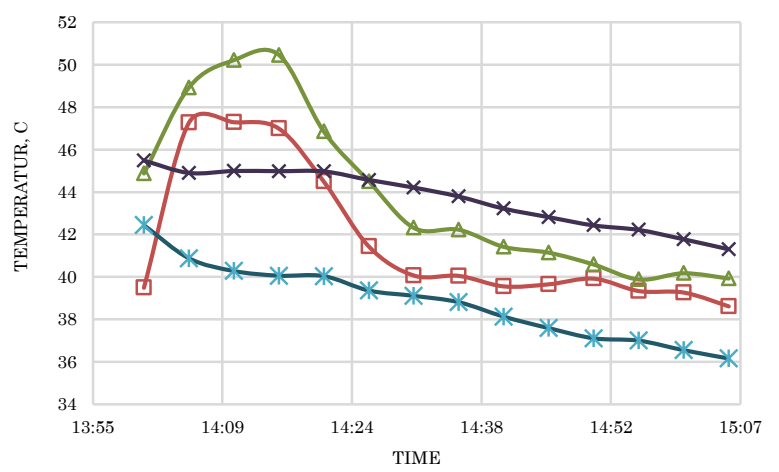

$\square$ atas kanan $\longrightarrow$ atas kiri $\longrightarrow$ bawah kanan $\longrightarrow$ bawah kiri

Gambar 8. Temperatur plat penyerap dengan lensa Fresnel

Gambar 9 menunjukkan temperatur plat dan cairan dalam tangki untuk penutup terbuat dari lensa Fresnel dan acrylic polos. Temperatur plat penyerap ketika menggunakan penutup lensa Fresnel sebelah kanan atas maupun kiri atas lebih tinggi daripada ketika menggunakan acrylic polos, meskipun lensa Fresnel buatan sendiri lebih buram dibandingkan acrylic polos jika dilihat pada Gambar 7. Temperatur maksimum di bagian kanan atas plat penyerap dengan lensa Fresnel dapat mencapai $65.32^{\circ} \mathrm{C}$, sedang temperature maksimum dengan acrylic polos hanya mencapai $51.19^{\circ} \mathrm{C}$ atau $78.4 \%$ dari lensa Fresnel. Temperatur maksimum di kiri atas plat penyerap dengan lensa Fresnel dapat mencapai 1.42 kali lebih tinggi dari temperatur maksimum dengan acrylic polos.

Intensitas radiasi matahari sangat mempengaruhi temperatur plat penyerap. Sedangkan temperatur cairan dalam tangki juga dipengaruhi temperatur sekitar lokasi pengujian, karena tangki tidak diisolasi. Tangki yang tidak diisolasi memberikan keuntungan ketika matahari bersinar terik, karena tangki dan cairan di dalamnya ikut menerima radiasi dan panas. Namun, ketika cuaca mendung, maka temperatur cairan dalam tangki dapat berkurang karena tangki melepas panas ke sekitarnya.

Hal ini menunjukkan radiasi matahari yang terpusat keenam titik focus dari lensa Fresnel dapat meningkatkan temperatur plat penyerap. Namun, temperatur cairan dalam tangki dengan lensa Fresnel tidak terlalu tinggi dibanding temperatur cairan dalam tangki dengan acrylic. Hal ini kemungkinan karena bahan pipa yang digunakan adalah besi yang mempunyai konduktivitas tidak terlalu tinggi. Konduktivitas termal tembaga murni adalah 401 $\mathrm{W} / \mathrm{m} . \mathrm{K}$, sedangkan konduktivitas dari aluminium murni dan besi murni adalah $237 \mathrm{~W} / \mathrm{m} . \mathrm{K}$ dan 80.2 W/m.K, secara berurutan (BERGMAN, et al., 2011). Jika pipa terbuat dari aluminium atau tembaga, perbedaan temperatur cairan jika menggunakan lensa Fresnel akan lebih nampak.

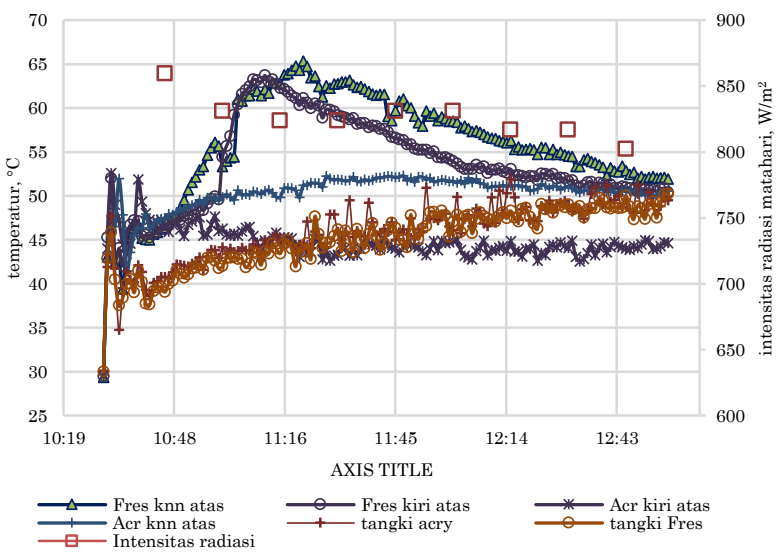

Gambar 9. Temperatur plat dan cairan dalam tangki untuk lensa Fresnel dan acrylic polos

Gambar 10 menunjukkan temperatur cairan pada inlet kolektor surya yang diukur pada titik dekat valve dan temperatur cairan dalam tangki di bagian atas dari kolektor surya sebagaimana terlihat dalam Gambar 7. Temperatur di inlet pada awalnya rendah sehingga hal ini menunjukkan cairan masih dalam keadaan dingin. Kemudian temperatur berangsur-angsur naik. Karena tanggal 29 November 2019 adalah hari yang cerah, maka intensitas radiasi matahari cukup tinggi, yaitu berkisar antara $500-$ $900 \mathrm{~W} / \mathrm{m}^{2}$ dan menyebabkan cairan dalam tangki mencapai temperatur lebih dari $50^{\circ} \mathrm{C}$. Dalam penelitian ini, intensitas radiasi matahari belum dapat dicatat dengan logger, sehingga data yang didapat hanya sebagian. Meskipun pengukuran intensitas radiasi tidak bisa kontinu, tetapi tetap memberikan informasi sumber energi matahari yang tersedia. Jika intensitas radiasi matahari rendah, tentu temperatur air/plat menurun dan kinerja kolektor terpengaruh. Dari Gambar 10 terlihat bahwa temperatur cairan pada inlet maupun dalam tangki pada kolektor surya yang menggunakan lensa Fresnel lebih tinggi daripada temperatur cairan yang dihasilkan dengan acrylic polos. Hal ini menunjukkan bahwa lensa Fresnel dapat meningkatkan temperatur cairan yang tersimpan di dalam tangki. Temperatur ini merupakan salah satu faktor yang menentukan kinerja kolektor surya. Dengan demikian, lensa Fresnel hasil rancangan sendiri ini dapat digunakan dengan baik sebagai penutup kolektor surya. Jika lensa Fresnel dapat dibuat dari kaca, tentu akan tampak bening sehingga radiasi matahari akan lebih banyak yang menembus dan 
difokuskan pada plat penyerap. Hal ini akan meningkatkan kinerja kolektor surya yang sangat bermanfaat bagi banyak proses paska panen hasil pertanian.

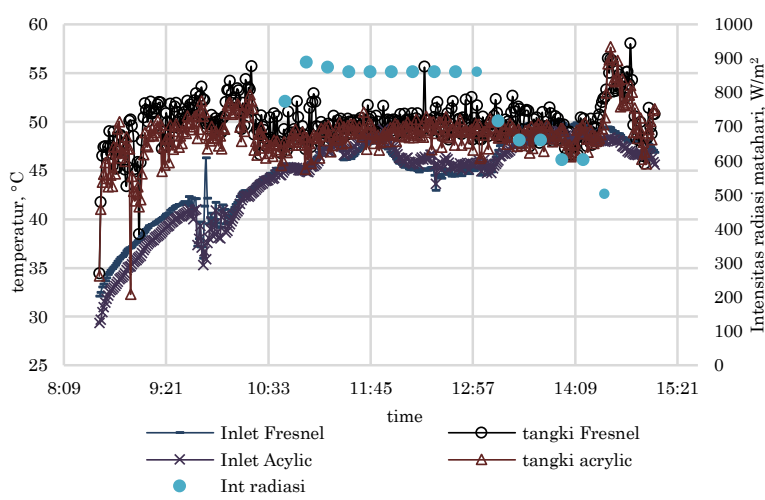

Gambar 10. Temperatur cairan pada inlet dan dalam tangki untuk lensa Fresnel dan acrylic polos

\section{KESIMPULAN}

Untuk meneliti pengaruh lensa Fresnel sebagai penutup pada suatu kolektor surya plat datar, suatu lensa Fresnel dirancang dengan enam titik focus. Jarak focus dirancang agar radiasi matahari jatuh ke plat penyerap pada jarak $90 \mathrm{~mm}$ dari lensa Fresnel. Bahan yang digunakan adalah PMMA (acrylic) dan pembuatan profil lensa menggunakan proses tekan. Lensa Fresnel yang dihasilkan benar memiliki jarak titik focus sesuai rancangan yaitu $90 \mathrm{~mm}$.

Lensa Fresnel yang dihasilkan dipasang sebagai penutup pada kolektor surya plat datar. Hasil yang didapat adalah bahwa temperatur plat penyerap dengan lensa Fresnel lebih tinggi daripada temperature plat penyerap dengan acrylic polos yang sebenarnya lebih bening. Temperatur maksimum di kiri atas plat penyerap dengan lensa Fresnel dapat mencapai 1.42 kali lebih tinggi dari temperatur maksimum dengan acrylic polos. Temperatur cairan di inlet dan dalam tangki pada kolektor surya yang menggunakan lensa Fresnel lebih tinggi daripada temperatur cairan pada kedua lokasi yang sama yang menggunakan acrylic polos.

Beberapa usulan untuk perbaikan penelitian meliputi: (1) lensa Fresnel dibuat lebih bening, (2) pipa sebaiknya terbuat dari bahan aluminium atau tembaga dan tangki diisolasi untuk mengurangi kehilangan panas jika cuaca mendung, dan (3) penggunaan logger untuk mencatat intensitas radiasi matahari dari waktu ke waktu untuk mendapatkan data yang berkesinambungan.

\section{DAFTAR PUSTAKA}

[1]. Bergman , T. L., Lavine, A. S., Incropera, F. P. $\&$ Dewitt , D. P., 2011. Fundamentals of Heat and Mass Transfer. 7th ed. s.l.:John Wiley \& Sons, Inc. .
[2]. Bhushan, B. \& Singh, R., 2010. A review on methodology of artificial roughness used in duct of solar air heaters. Energy , 35, pp 202-212.

[3]. Deb, G. \& Roy, A.B., 2012. Use of Solar Tracking System for Extracting Solar Energy. International Journal of Computer and Electrical Engineering, , 4, 1, pp. 42-46.

[4]. Esen, H., 2008. Experimental energy and exergy analysis of a double-flow solar air heater having different obstacles on absorber plates. Building and Environment, 43, pp 1046-1054.

[5]. Gao, W. F., Lin, W. X., Tao Liu, L. \& Xia, C.F., 2007. Analytical and experimental studies on the thermal performance of cross-corrugated and flat-plate solar air heaters. Applied Energy 84, pp $425-441$.

[6]. Handoyo, E. A., Bisono, I. N., Jonathan, P. \& Valentio, D., 2020. Effect of Fresnel lens as cover in a passive solar water heater with some air gap between cover and absorber plate. IOP Conference Series: Materials Science and Engineering, 740, pp. 1-7.

[7]. Handoyo, E. A., Ichsani, D. \& Prabowo, 2013. The optimal tilt angle of a solar collector. Energy Procedia, 32, pp $166-175$.

[8]. Handoyo, E. A., Ichsani, D., Prabowo \& Sutardi, 2014. Experimental Studies on a Solar Air Heater Having V-Corrugated. Applied Mechanics and Materials, 493, pp. 86-92.

[9]. Handoyo, E. A., Ichsani, D., Prabowo \& Sutardi, 2016. Numerical studies on the effect of deltashaped obstacles' spacing on the heat transfer and pressure drop in v-corrugated channel of solar air heater. Solar Energy, 131, pp 47-60.

[10]. Kasaeian, A., Tabasi, S., Ghaderian, J. \& Yousefi, H., 2018. A review on parabolic trough/ Fresnel based photovoltaic thermal systems. Renewable and Sustainable Energy Reviews, 91, pp. 193-204.

[11]. Külcü, R., 2017. Design of Serial Connected Vacuum Tube Solar Air Collector. European Scientific Journal, Volume special edition ISSN: 1857 - 7881, pp. 32-37.

[12]. Kumar, V., Shrivastava, R. \& Untawale, S., 2015. Fresnel lens: A promising alternative of reflectors in concentrated solar power. Renewable and Sustainable Energy Reviews, 44, p. 376390.

[13]. Leutz, R. \& Suzuki, A., 2001. Nonimaging Fresnel Lenses: Design and Performance of Solar Concentrators. Berlin: Springer Series in Optical Sciences.

[14]. Luminosu, I., De Sabata, A. \& Jurca, T., 2017. Thermal Solar Experimental Model Equipped With Fresnel Lenses. Buletinul 104 AGIR nr. 1, ianuarie-martie, pp. 104-110.

[15]. Romdhane, B. S., 2007. The air solar collectors: Comparative study, introduction of baffles to favor the heat transfer. Solar Energy, Volume 81 , p. $139-149$. 
[16]. Sonneveld, P. J. et al., n.d. A Fresnel Lenses Based Concentrator PV System in a Greenhouse, Netherlands: s.n.

[17]. Soriga, I. \& Neaga, C., 2012. Thermal Analysis of a Linear Fresnel Lens Solar Collector with Black Body Cavity Receiver. U.P.B. Sci. Bull., Series D, Volume Vol. 74, Iss. 4, pp. 105-116.

[18]. Xie, W. T., Dai, Y. J., Wang, R. Z. \& Sumathy, K., 2011. Concentrated solar energy applications using Fresnel lenses: A review. Renewable and Sustainable Energy Reviews, Volume 15, pp. 2588-2606.
[19]. Yeh, H.-M. \& Ho, C.-D., 2009. Effect of external recycle on the performances of flat-plate solar air heaters with internal fins attached. Renewable Energy, Volume 34, pp. 1340-1347.

[20]. Zhang, H., Baeyens, J., Degrève, J. \& Cacères, G., 2013. Concentrated solar power plants: Review and design methodology. Renewable and Sustainable Energy Reviews, Volume 22, pp. 466-481.

[21]. Zhu, G., Wendelin, T., Wagner, M. J. \& Kutscher, C., 2014. History, current state, and future of linear Fresnel concentrating solar collectors. Solar Energy 103, pp. 639-652. 